\title{
STRESS CONCENTRATORS POSITIONING MODES AND DETERMINATION OF THE STRESS CONCENTRATION FACTOR USING FEM. ESTABLISHING CRACKING SCENARIOS TO DETERMINE THE CHARACTERISTICS OF THE CRACK
}

\author{
Anişoara - Gabriela Cristea \\ "Dunarea de Jos" University of Galati, \\ Faculty of Naval Architecture, Galati, Domneasca Street, No. 47, 800008, Romania, \\ E-mail: anisoara.cristea@ugal.ro
}

\begin{abstract}
This paper shows the effects of variable stresses acting on structures, the positioning modes of stress raisers, as well as the determination of stress concentration factor and the establishment of some cracking scenarios in order to determine the main characteristics of the crack.

The problem of numerical analysis of various engineering problems is not new; it has been used over the centuries.

A classification of numerical modeling methods can be done mathematically in 3 main directions: finite difference method, finite element method and method of border elements. The structural analysis has the following stages: determining the type of analysis, modeling the structure and of the boundary conditions, the actual analysis.

The area taken into consideration was the structure of the double bottom, which is composed of the following elements, namely: the floor to the bottom floor of the double bottom, lateral support, and bottom longitudinal to double bottom longitudinal.

The numerical analyses were performed using the program SolidWorks Cosmos/M of the cumulative damage factor. In most cases the structures made of composite materials are complex structures due to the material and in most cases they must be verified in terms of the endurance strength.
\end{abstract}

Keywords: normal stresses, concentration factor, intensity factor, numerical modeling.

\section{INTRODUCTION}

The study of this paper concerns a vessel to transport chemical compounds (chemical tanker) of $49000 \mathrm{tdw}$. All references to naval structures have this vessel as target.

For modeling and stress analysis around relief cutting of a frame floor, the program system with SolidWorks/COSMOS/M [6] finite element was used.
This type of vessel is built in framework longitudinal system. Its main sizes are presented in the table below (Table 1).

Using Germanischer Lloyd, Poseidon program, for chemical tanker considered being studied, the preliminary structural model was made, in accordance with local and general resistance rules. 


\section{DESCRIPTION AND REALIZATION OF THE NUMERICAL MODEL}

The problem of numerical analysis of various engineering problems is not new; it has been used over the centuries.

A classification of numerical modeling methods can be done mathematically in 3 main directions: finite difference method, finite element method and method of border elements. Structural analysis has the following stages: determining the type of analysis, modeling the structure and of the boundary conditions, the actual analysis.

The ship is a chemical tanker, it has 6 holds, a single propeller, bulbous bow and the superstructure is located above the engine room.

Table 1. Main dimensions and characteristics of steel.

Table 1 Results of the analysis

\begin{tabular}{|c|c|}
\hline \multicolumn{2}{|c|}{ Main dimensions } \\
\hline Maximum length & $182.85 \mathrm{~m}$ \\
\hline $\begin{array}{c}\text { Length between per- } \\
\text { pendiculars }\end{array}$ & $175.00 \mathrm{~m}$ \\
\hline Width & $32.2 \mathrm{~m}$ \\
\hline Construction height & $18 \mathrm{~m}$ \\
\hline Draft & $12.6 \mathrm{~m}$ \\
\hline Speed & $14.4 \mathrm{Nd}$ \\
\hline Characteristics of steel \\
\hline Modulus of elasticity & $210 \mathrm{GPa}$ \\
\hline Poisson's ratio & 0.3 \\
\hline Density of steel & $7.850 \mathrm{~kg} / \mathrm{m}^{3}$ \\
\hline
\end{tabular}

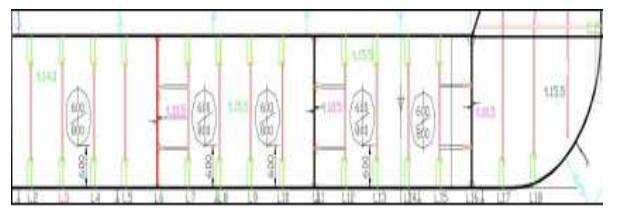

Fig. 1 Detail of the analyzed structure area

The 3D model of the structure was created using the COSMOS software. There are several available elements in COSMOS. We have used PLANE2D two-dimensional elements in the case of the floor and more complex Thick Shell (Shell4T) elements for the rest of the structure.

The structure of the double bottom was embedded at one end and at the other end it was loaded with loads of $300 \mathrm{kN}$, at the junction between bilge and plate of the double bottom.

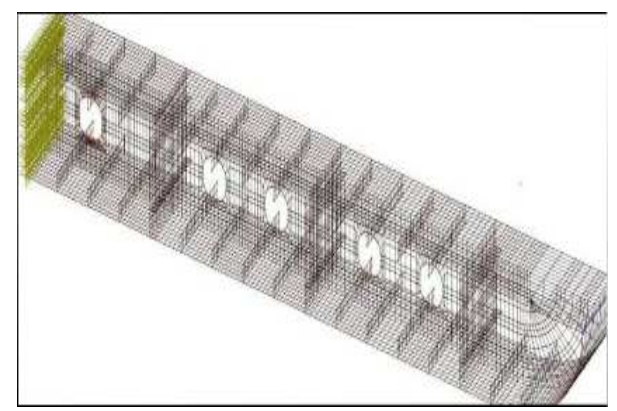

Fig. 2 Meshed structure, boundary and loading conditions

\section{VARIATION OF INDIRECT STRESS THAT OCCURS IN THE STRUCTURE OF THE DOUBLE BOTTOM (DB), IN THE AREA OF TECHNOLOGICAL CUTOUTS}

The numerical results obtained from the analysis in the area of technological cutouts are shown in table 2. According to this analysis, the stresses in the structure vary between $120.69 \mathrm{MPa}$ and 193.1MPa.

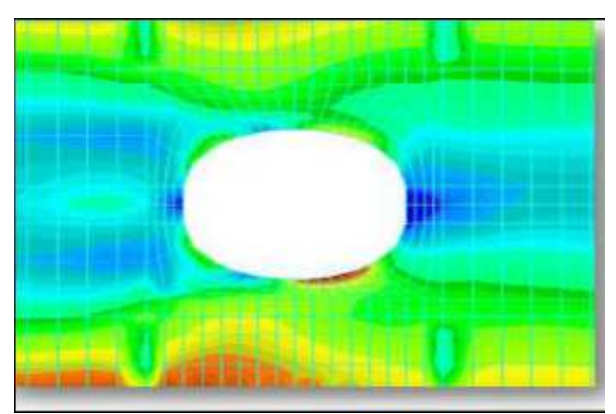

Fig. 3 Variation of indirect stress 


\section{POSITIONING OF THE STRESS CONCENTRATION FACTOR. DETERMINATION OF THE STRESS CONCENTRATIONS FACTOR WITH FEM}

Fatigue is an insidious type of timedependent failure that can occur without any obvious warning. It is believed that more than $95 \%$ of all mechanical failures can be attributed to fatigue. Normally, there are three distinct stages in fatigue failure of a component, namely: crack initiation, incremental crack growth, and final fracture.

Fracture is the separation of a whole component into at least two parts. This separation may also occur locally due to the formation and increase of cracks. Let us investigate the necessary force for such a separation in a very fundamental way.

Determination of stress [2]: it is based on a linear extrapolation system, in each of the two locations adjacent to the stress concentrator.

Formula (1) allows the calculation of stress at the most stressed point, thus determining with linear extrapolation, stress concentration factor for every location that is considered dangerous.

$$
\sigma_{h o t}=1,5 \sigma_{0,5 t}-0,5 \sigma_{1,5 t}
$$

However, in practice, the increase in cracks can occur in very complicated stress fields. Generally, we take into consideration three basic ways of crack growth, although mixed growth is also possible [5].

To determinate stress concentration factor, the area of technological cutouts in the double bottom is taken into account.

A single radius of connection with various loaded forces from $300 \mathrm{kN} \div 400 \mathrm{kN}$ was taken into consideration (Case 2D- Floor thickness $14.5 \mathrm{~mm}$; Case 2D- Floor thickness $15 \mathrm{~mm}$; Case 2D- Floor thickness $16.5 \mathrm{~mm}$ ).

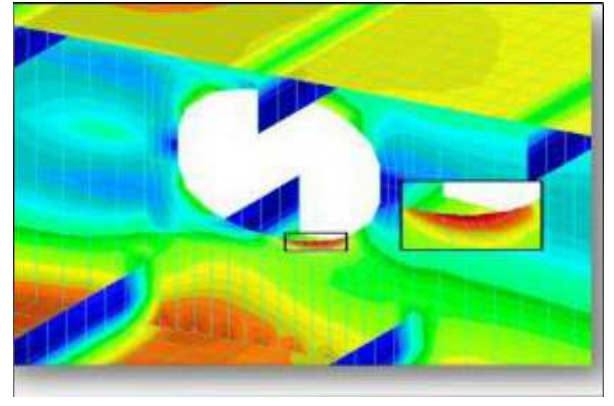

Fig. 4 Highlighting the stress concentrator

In this case, determination of stress concentration factor was made by fine meshing method.

Fine meshing - floor_thickness _14.5 $\mathrm{mm}, 15 \mathrm{~mm}, 16.5 \mathrm{~mm}$

For this meshing an element size of about $8 \mathrm{~mm}$ was used in the area of technological cutout.

\section{THE OCCURRENCE AND EXTENSION OF CRACKS IN THE AREA OF TECHNOLOGICAL CUTOUTS IN THE REINFORCEMENTS OF THE DOUBLE BOTTOM. DETERMINATION OF PARAMETERS SPECIFIC TO THE PROPAGATION OF CRACKS}

Generally, we take into consideration three basic ways of crack growth, although mixed growth is also possible: mode I is the opening or traction mode; mode II, elongated or planar shearing mode; in the crack mode or in the antiplane, mode III, the faces of the crack align with each other [1].

For a crack in a linear elastic material, J integral represents an energy release rate. Also, the amplitudes of the stress and deformation fields of the tip of crack are characterized by $\mathrm{J}$ integral for a crack in a nonlinear elastic material. 
Table 2 Determination of the concentration factor with FEM SFCfin

\begin{tabular}{|c|c|c|c|c|c|c|c|c|}
\hline \begin{tabular}{|c|} 
Quata to \\
extract \\
stress
\end{tabular} & $\begin{array}{l}\text { Force } \\
{[\mathrm{kN}]}\end{array}$ & \begin{tabular}{|c|} 
Stress \\
Von-Mise \\
{$\left[\mathrm{N} / \mathrm{mm}^{2}\right]$} \\
\end{tabular} & $\begin{array}{c}\text { Quata to } \\
\text { extract } \\
\text { stress }\end{array}$ & $\begin{array}{c}\text { Force } \\
{[\mathrm{kN}]}\end{array}$ & \begin{tabular}{|c|} 
Stress \\
Von-Mise \\
{$\left[\mathrm{N} / \mathrm{mm}^{2}\right]$} \\
\end{tabular} & \begin{tabular}{|c|}
$\begin{array}{c}\text { Quata to } \\
\text { extract } \\
\text { stress }\end{array}$ \\
\end{tabular} & $\begin{array}{l}\text { Force } \\
{[\mathrm{kN}]}\end{array}$ & \begin{tabular}{|c} 
Stress \\
Von-Mise \\
{$\left[\mathrm{N} / \mathrm{mm}^{2}\right]$} \\
\end{tabular} \\
\hline \multicolumn{3}{|c|}{$\begin{array}{c}\text { Structure floor }{ }_{-} \text {thickness } \\
14.5[\mathrm{~mm}]\end{array}$} & \multicolumn{3}{|c|}{\begin{tabular}{|c|} 
Structure floor ${ }_{-}$thickness \\
$15[\mathrm{~mm}]$
\end{tabular}} & \multicolumn{3}{|c|}{$\begin{array}{c}\text { Structure floor_thickness } \\
16.5[\mathrm{~mm}]\end{array}$} \\
\hline $0.5 \mathrm{t}$ & \multirow{3}{*}{300} & 137.6 & $0.5 \mathrm{t}$ & \multirow{3}{*}{300} & 146.3 & $0.5 \mathrm{t}$ & \multirow{3}{*}{300} & 148.7 \\
\hline $1.5 \mathrm{t}$ & & 95.5 & $1.5 \mathrm{t}$ & & 94.87 & $1.5 \mathrm{t}$ & & 93.01 \\
\hline $\begin{array}{l}\text { The value } \\
\text { of SCFfin }\end{array}$ & & 158.65 & $\begin{array}{l}\text { The value } \\
\text { of SCFfin }\end{array}$ & & 172.02 & $\begin{array}{l}\text { The value } \\
\text { of SCFfin } \\
\end{array}$ & & 176.54 \\
\hline $0.5 \mathrm{t}$ & \multirow{3}{*}{350} & 160.6 & $0.5 \mathrm{t}$ & \multirow{3}{*}{350} & 170.6 & $0.5 \mathrm{t}$ & \multirow{3}{*}{350} & 173.5 \\
\hline $1.5 \mathrm{t}$ & & 106.9 & $1.5 \mathrm{t}$ & & 110.7 & $1.5 \mathrm{t}$ & & 108.5 \\
\hline $\begin{array}{l}\text { The value } \\
\text { of SCFfin }\end{array}$ & & 187.45 & $\begin{array}{l}\text { The value } \\
\text { of SCFfin }\end{array}$ & & 200.55 & $\begin{array}{l}\text { The value } \\
\text { of SCFfin }\end{array}$ & & 206 \\
\hline $0.5 \mathrm{t}$ & \multirow{3}{*}{400} & 183.5 & $0.5 \mathrm{t}$ & \multirow{3}{*}{400} & 195 & $0.5 \mathrm{t}$ & \multirow{3}{*}{400} & 198.3 \\
\hline $1.5 \mathrm{t}$ & & 122.2 & $1.5 \mathrm{t}$ & & 126.5 & $1.5 \mathrm{t}$ & & 124 \\
\hline $\begin{array}{l}\text { The value } \\
\text { of SCFfin }\end{array}$ & & 214.15 & $\begin{array}{l}\text { The value } \\
\text { of SCFfin }\end{array}$ & & 229.25 & $\begin{array}{l}\text { The value } \\
\text { of SCFfin }\end{array}$ & & 235.45 \\
\hline
\end{tabular}

The characteristics of the crack, such as stress intensity factor $\left(\mathrm{K}_{\mathrm{I}}, \mathrm{K}_{\mathrm{II}}\right)$, are evaluated using the $\mathbf{J}$ integral. It can be demonstrated that this integration is independent [4].

Verification of $\mathbf{J}$ integral value can be done using the relation:

$$
J=\frac{K^{2}}{E}
$$

where:

$\mathrm{K}$ - is the stress intensity factor;

E - represents the modulus of elasticity of the material

In order to determine the stress intensity factor $\mathrm{K}$ and $\mathrm{J}$ integral, the area of technological cutouts in the reinforcements of the double bottom (DB) with a fillet radius of $150 \mathrm{~mm}$ was taken into consideration.

The results obtained from numerical calculations were centralized in diagrams where the variation of the $\mathrm{J}$ integral and of the stress factor $\mathrm{K}$ was also highlighted.

Table 3 summarizes the results of $\mathrm{J}$ integral in the cutouts area and table 4 show the values of stress intensity factor and, for each step of the extension of the crack.

\section{CONCLUSIONS}

Determination of the modes of cracking necessary for the extension of the crack was an important point in evaluating and determining damages that occur during operation in structures made of steel.

Most times, the analysis of the emergence and extension of cracks can be achieved only by using numerical and experimental methods.

The coefficients specific to the cracking process, which indicate the direction of crack extension, have been therefore determined.

The most important sizes specific to crack theory, the stress intensity factor, the speed of energy release and the $\mathrm{J}$ integral were defined. 
Table 3 J-integral for the four structure

\begin{tabular}{|c|c|c|c|c|c|}
\hline \multirow{2}{*}{ Structure } & \multirow{2}{*}{$\begin{array}{c}\text { Force } \\
{[\mathrm{kN}]}\end{array}$} & $\begin{array}{c}\text { Scenario } \\
\text { I }\end{array}$ & $\begin{array}{c}\text { Scenario } \\
\text { II }\end{array}$ & $\begin{array}{c}\text { Scenario } \\
\text { III }\end{array}$ & $\begin{array}{c}\text { Scenario } \\
\text { IV }\end{array}$ \\
\hline \multirow{2}{*}{$\begin{array}{c}\text { Floor_ } \\
\text { thickness } \\
\text { _14.5 mm }\end{array}$} & 300 & 79.70 & 163.56 & 183.91 & 217.90 \\
\cline { 2 - 6 } & 350 & 108.49 & 290.71 & 250.4 & 296.66 \\
\cline { 2 - 6 } & 400 & 141.17 & 430.23 & 327.02 & 387.5 \\
\hline \multirow{2}{*}{$\begin{array}{c}\text { Floor_ } \\
\text { thickness } \\
\text { _15 mm }\end{array}$} & 300 & 81.12 & 165.89 & 186.32 & 220.80 \\
\cline { 2 - 6 } & 350 & 110.04 & 225.23 & 253.71 & 300.67 \\
\hline \multirow{2}{*}{$\begin{array}{c}\text { Floor_ } \\
\text { thickness } \\
\text { _16.5 mm }\end{array}$} & 300 & 144.42 & 294.86 & 331.21 & 392.6 \\
\cline { 2 - 6 } & 400 & 85.15 & 172.41 & 192.89 & 228.98 \\
\cline { 2 - 6 } & 115.9 & 234.74 & 262.54 & 311.61 \\
\hline \multirow{2}{*}{} & 151.3 & 306.57 & 342.82 & 407.07 \\
\hline
\end{tabular}

Table 4 Stress intensity factor $K_{I}, K_{I I}$ for both structures

\begin{tabular}{|c|c|c|c|c|c|c|c|c|c|}
\hline \multirow[t]{2}{*}{ Structure } & \multirow[t]{2}{*}{$\begin{array}{c}\text { Force } \\
{[\mathrm{kN}]}\end{array}$} & \multicolumn{4}{|c|}{$\begin{array}{c}K_{I} \text { factor variation depending on } \\
\text { the length of the crack } \\
{\left[\mathrm{N} / \mathrm{mm}^{0.5}\right]}\end{array}$} & \multicolumn{4}{|c|}{$\begin{array}{c}K_{I I} \text { factor variation de- } \\
\text { pending on the length of } \\
\text { the crack } \\
{\left[\mathrm{N} / \mathrm{mm}^{0.5}\right]}\end{array}$} \\
\hline & & $\begin{array}{c}\text { Scen. } \\
\text { I }\end{array}$ & $\begin{array}{c}\text { Scen. } \\
\text { II }\end{array}$ & $\begin{array}{c}\text { Scen. } \\
\text { III }\end{array}$ & $\begin{array}{c}\text { Scen. } \\
\text { IV }\end{array}$ & $\begin{array}{c}\text { Scen. } \\
\text { I }\end{array}$ & $\begin{array}{c}\text { Scen. } \\
\text { II }\end{array}$ & $\begin{array}{c}\text { Scen. } \\
\text { III }\end{array}$ & $\begin{array}{l}\text { Scen. } \\
\text { IV }\end{array}$ \\
\hline \multirow{3}{*}{$\begin{array}{l}\text { Floor_ } \\
\text { thicknes } \\
\mathrm{s}_{1} 14.5 \\
\mathrm{~mm}\end{array}$} & 300 & 8750.7 & 13162.5 & 11745.4 & 8781.9 & 31318.2 & 29959.7 & 31611.1 & 31814.5 \\
\hline & 350 & 10209.1 & 16555.2 & 14141.7 & 10527.5 & 36954.8 & 36945.1 & 36545.5 & 36855.5 \\
\hline & 400 & 11667.2 & 19560 & 17134.2 & 11894.8 & 41991.2 & 42234.4 & 42414.4 & 41886.6 \\
\hline \multirow{3}{*}{$\begin{array}{l}\text { Floor_ } \\
\text { thicknes } \\
\mathrm{s} \_15 \\
\mathrm{~mm}\end{array}$} & 300 & 8725.9 & 13127.1 & 11241.1 & 8656.8 & 30743.3 & 29866.7 & 30141.8 & 30740.6 \\
\hline & 350 & 10180.3 & 15313.5 & 13143.5 & 10099.1 & 35861.7 & 34868.9 & 34991.6 & 35864.4 \\
\hline & 400 & 11634.6 & 17502 & 15932.1 & 11542.4 & 40991.1 & 39849.2 & 40141.5 & 40989.7 \\
\hline \multirow{3}{*}{$\begin{array}{l}\text { Floor_- } \\
\text { thicknes } \\
\text { s_16.5 } \\
\text { mm }\end{array}$} & 300 & 8566.2 & 12896.4 & 11432.1 & 8498.8 & 30249.4 & 29409.2 & 29932.4 & 30248.9 \\
\hline & 350 & 9940.2 & 15046.2 & 13043.6 & 9915.1 & 35219.1 & 34311.1 & 34444.4 & 35290.5 \\
\hline & 400 & 11421 & 17195.3 & 15310.4 & 11331.1 & 40322.6 & 39211.6 & 40112.2 & 40331.7 \\
\hline
\end{tabular}




\section{REFERENCES}

[1]. Dumitru, I., Marşavina, L., "Elemente de mecanica ruperii, - curs", Univ. "Politehnica" Timişoara, 2000.DOWD, T., Port Management Control System, Univ. of Washington, (1983)

[2]. Cristea A-G., "Contribuţii privind optimizarea structurilor de navă", Teză de doctorat, Galaţi, 2014

[3]. Hadăr A., Constantinescu I.N., Gheorghiu H., Coteț C.E., "Modelare şi modele pentru calcule în ingineria mecanică", Editura PRINTECH, Bucureşti, (2007)
[4]. Irwin, G.R., "Relation of stresses near a crack to the crack extension force", Proc. 9th Int. Congr. Appl. Mech, Vol. VIII: 245-251, University of Brussels, (1957)

[5]. Rice J.R., "A path independent integral and the approximate analysis of strain concentration by notches and cracks", J. Appl. Mech., 35: 379-386, (1968)

[6]. ***SWCM, SolidWorks Cosmos/M FEM Program User Guide, Dassault Systems SolidWorks Corporation, (2008)

Paper received on December $31^{\text {th }}, 2018$ 